\title{
Syfilis og blodtransfusjon
}

\begin{abstract}
Sammendrag
Bakgrunn. I 2007 ble det påvist gjennomgått syfilis hos en blodgiver som hadde gitt blod jevnlig i 15 år. Dette ble oppdaget fordi vedkommende skiftet blodbank og der ble syfilistestet som ny giver. Tidspunktet for smitte er ikke kjent. En ekspertgruppe nedsatt av Sosial- og helsedirektoratet fikk i oppdrag å vurdere risikoen for overføring av syfilis gjennom blodprodukter i Norge.
\end{abstract}

Materiale og metode. Ekspertgruppen baserte sine vurderinger på kunnskap om syfilissykdommens utbredelse, smitterisikoen og egenskaper ved syfilisbakterien, spesielt i forbindelse med blodgivning. I tillegg ble informasjon innhentet av Sosial- og helsedirektoratet vedrørende syfilistesting knyttet opp til den aktuelle hendelse vurdert.

Resultater. Av 54 blodmottakere var 21 i live. 18 (86\%) ble syfilistestet, alle med negativt resultat. For 11 avdøde ble journalgjennomgang utført, uten at det ble avdekket holdepunkter for syfilissmitte.

Fortolkning. Risikoen for transfusjonsoverført syfilis er svært lav. Dette har flere grunner: Forekomsten av smitteførende syfilis i befolkningen er lav, spørreskjema og intervju før donasjon selekterer bort syke og givere med smitterisiko, andelen blod som gis frisktappet er svært lav og syfilisbakteriene drepes ved normale lagringsbetingelser. Eventuell smitte gir symptomatisk sykdom som er lett tilgjengelig for antibiotikabehandling.

Ekspertgruppen anbefaler at man ikke starter syfilistesting av hver donasjon nå, men beholder dagens testing av nye givere.

\author{
Pål A. Jenum \\ pal.jenum@vestreviken.no \\ Seksjon for medisinsk mikrobiologi \\ Laboratoriesenteret \\ Sykehuset Asker og Bærum \\ Postboks 83 \\ 1309 Rud
}

Øystein Flesland

Nasjonal kunnskapssenter for helsetjenesten

Hans Blystad

Avdeling for infeksjonsforebygging

Inger Sofie Samdal Vik

Virologisk avdeling

Divisjon for smittevern

Nasjonalt folkehelseinstitutt

\section{Tor Hervig}

Blodbanken

Haukeland universitetssykehus og

Gades Institutt

\section{Arild Mæland}

Medisinsk avdeling

\section{Gunnar Sæter}

Fagavdelingen

Oslo universitetssykehus, Ullevål

I oktober 2007 mottok Folkehelseinstituttet et varsel fra medisinsk poliklinikk ved sykehus $\mathrm{A}$ om at det var påvist syfilisantistoffer hos en for dem ny blodgiver. Av meldingen fremgikk det at vedkommende tidligere $\mathrm{i}$ flere år hadde gitt blod ved blodbanken ved sykehus B. Den gang vedkommende i 1993 var ny blodgiver der, ble det ikke påvist syfilisantistoffer. Det kunne derfor synes som om syfilissmitten hadde funnet sted på et eller annet tidspunkt innen de siste 15 årene mens pasienten var aktiv som blodgiver ved sykehus B. Det kunne ikke utelukkes at syfilissmitteførende blod var gitt til en eller flere mottakere i det aktuelle tidsrom.

Sosial- og helsedirektoratet nedsatte umiddelbart en ekspertgruppe for å klarlegge forhold omkring denne hendelsen og vurdere eventuelle tiltak. I denne artikkelen omtales relevante forhold omkring syfilis og blodgivning med utgangspunkt i den aktuelle hendelsen og gruppens rapport.

\section{Materiale og metode}

De generelle vurderingene er basert på kunnskap om syfilissykdommen, syfilisbakterien og smitteutbredelse av betydning i blodgiversammenheng, hentet fra tilgjengelig litteratur. Opplysninger om smitteoppsporing i relasjon til aktuelle blodgiver er stilt til rådighet for gruppen av Sosial- og helsedirektoratet. Disse opplysningene er vurdert ut fra denne generelle kunnskapen.

\section{Syfilissykdommen}

Syfilis forårsakes av spiroketebakterien Treponema pallidum ssp pallidum. Bakterien overføres i hovedsak ved seksuell kontakt med smitteførende person gjennom slimhinneinokulasjon. Sykdommen inndeles i ulike stadier - tidlig syfilis omfatter primær, sekundær og tidlig latent syfilis, sen syfilis omfatter sen latent og tertiær syfilis (1).

Primær syfilis opptrer etter en inkubasjonstid på tre uker (9-90 dager) og karakteriseres av et avgrenset, kraterliknende, hardt og uømt sår på inokulasjonsstedet (hard sjanker). Pasienter med primær syfilis vil ha både spesifikke treponemaantistoffer og kardiolipinantistoffer i blodet i økende mengde.

Sekundær syfilis opptrer 4-8 uker etter primærstadiet, eller 6 uker -6 md. etter smitte. Bakteriene er da disseminert til hele kroppen og kan gi symptomer fra ethvert organsystem. I dette stadiet inneholder blodet og alle sekreter og vev store mengder syfilisbakterier. En pasient med sekundær syfilis har klare kliniske sykdomstegn, og antistoffnivået mot syfilisbakterien er meget høyt.

Ubehandlet går sekundærstadiet over i tidlig latent fase, som varer til ett år etter smitte. I løpet av denne tiden forsvinner symptomene gradvis og smittsomheten avtar. Grensen på ett år er noe vilkårlig satt, men gir god margin for opphør av seksuell smittsomhet. Tidlig syfilis, som omfatter primær, sekundær og tidlig latent syfilis, definerer dermed tidsrommet for når syfilispasienter kan smitte andre. Det er anført at om lag en tredel av de smittede bekjemper

\section{Hovedbudskap}

- Ett tilfelle av nyoppdaget syfilissmitte hos etablert blodgiver er gjennomgått

- Ingen blodmottakere er påvist syfilisinfisert

- Risikoen for transfusjonsmediert syfilissmitte er ytterst liten

- Anbefalingen fra en ekspertgruppe er at man ikke tester for syfilisantistoff ved hver bloddonasjon 
infeksjonen og eliminerer bakterien helt og blir friske (1).

To tredeler av de smittede vil gå over til sen latent fase, hvor bakterien fortsatt er til stede i kroppen i lite antall i mer enn ett år etter smitten, men uten å gi kliniske symptomer. Om lag halvparten av disse pasientene forblir asymptomatiske livet ut, den andre halvparten vil utvikle tertiær syfilis fra tre år til flere tiår senere, med symptomer fra ett eller flere affiserte organsystemer $(1,2)$. De spesifikke treponemaantistoffene i blodet kan påvises livet ut, mens kardiolipinantistoffene vil kunne forsvinne etter noen år $(2,3)$.

\section{Syfilisbakterien}

På tross av sin høye smittsomhet og sitt potensial for utvikling av alvorlig og kronisk sykdom, er Treponema pallidum en meget «følsom» bakterie. Den kan ikke dyrkes på cellefrie medier eller i cellekultur (4). Bakterien er strikt anaerob, det vil si at den dør når oksygentrykket kommer over $1-4 \%$. Den er også kuldefølsom og dør ved kjøleskapstemperatur. Den er meget følsom for så å si alle vanlige antibiotika, men siden den i latent fase er lite metabolsk aktiv, er høye penicillindoser over noen tid anbefalt, spesielt dersom sentralnervesystemet er involvert (1).

\section{Utbredelsen av syfilis}

Syfilisinsidensen i Norge falt dramatisk etter den annen verdenskrig, og etter midten av 1980-årene var sykdommen sjelden i Norge. Fra 1999 har man igjen observert en økning av smitteførende syfilis. Mens det til Meldingssystem for smittsomme sykdommer (MSIS) i 1998 ble meldt 11 syfilistillfeller, økte insidensen til 53 tilfeller i $1999(1,2$ per 100000 innbyggere). Økningen skyldes at syfilis igjen fikk fotfeste i det homoseksuelle miljøet i Norge. I dag er nesten $90 \%$ av meldte tilfeller forårsaket av homoseksuell smitte, og $80 \%$ av tilfellene er meldt fra Oslo. I 2007 ble det meldt i alt 61 smittede, hvorav kun sju var heteroseksuelt smittet. Av disse var fem smittet i utlandet (5).

\section{Syfilissmitte ved transfusjon}

Betingelser for blodoverført smitte er at blodgiveren har levende syfilisbakterier $\mathrm{i}$ blodet, at bakteriene overlever tapping og lagring før transfusjonen finner sted og at bakteriene formerer seg i blodmottakeren. Hos blodmottakeren er det ikke noe spesifikt inokulasjonssted, og infeksjonen utvikler seg derfor direkte til sekundærstadiet med disseminert infeksjon. Dersom blodmottakeren får blod med levende bakterier, vil det med stor sannsynlighet inntreffe en infeksjon, med mindre blodmottakeren får antibiotika på transfusjonstidspunktet. Da vil både smitte og antistoffdanning kunne forhindres.

Det har vært knyttet usikkerhet til spørsmålet om hvorvidt syfilis kan overføres ved bloddonasjon fra blodgiver i sen latent fase, siden bakterien åpenbart kan overleve i vev og senere gi sykdom (1). Flere undersøkelser støtter imidlertid antakelsen at blodoverført smitte i slike situasjoner ikke finner sted. Eberson \& Engman kom allerede i 1921 med en undersøkelse hvor blod fra 71 pasienter med sen latent syfilis ble podet på kaniner uten at noen av dyrene ble syfilissmittet (6). I 1935 gjennomgikk Morgan 16 tilfeller av transfusjonsassosiert syfilis. I ti av de 11 tilfellene som kunne evalueres, ble smitten tilskrevet en donor i tidlig fase av sykdommen. I ett tilfelle ble donor smittet av mottaker gjennom direkte transfusjon (!) (7). I 2002 rapporterte Orton og medarbeidere at det ikke hos noen av 169 undersøkte pasienter der det var serologisk holdepunkt for sen latent syfilis, ble funnet DNA fra Treponema pallidum i blodet med polymerasekjedereaksjonsteknikk (8). Endelig - det er ikke rapportert om transfusjonsbetinget syfilis i USA i de siste 30 år (9).

\section{Blodgivning og testing for syfilis}

Diagnosen aktuell eller tidligere syfilis stilles i dag på basis av kliniske funn og anamnestisk og epidemiologisk informasjon og bekreftes mikrobiologisk ved påvisning av antistoffer mot treponemabakterien. I smittsom fase vil pasienten ha økende, til dels meget høye antistoffnivåer, både spesifikke mot treponemabakterien og kardiolipinantistoffer og også spesifikke IgM-antistoffer (3).

Frem til 1982 ble alle bloddonasjoner screenet for syfilis med kardiolipinantistofftest. Denne testen har svakheter både når det gjelder sensitivitet og spesifisitet. Ved meget høye antistoffnivåer kan testen bli falskt negativ på grunn av såkalt prosonefenomen, det vil si at de mest smitteførende pasienter ikke blir oppdaget $(1,4)$. Testen kan også bli negativ i sen latent fase. Det betyr at tidligere syfilissmitte ikke erkjennes. Falskt positive resultater forekommer også, forbigående eller permanent, uten relasjon til syfilissmitte $(1,4)$. Dette innebærer at et positivt funn $i$ testen har meget lav positiv prediktiv verdi for diagnosen syfilis.

I 1982 ble det etter en grundig faglig gjennomgang besluttet at man ikke skulle teste blodgivere ved hver donasjon. Testing skulle kun gjøres ved registrering av giveren ved første oppmøte og da primært som surrogatmarkør på uønsket risikoatferd. Beslutningen var basert på en totalvurdering av risikoen for smitte til mottaker ut fra den lave forekomsten av smittsom syfilis i befolkningen, sannsynligheten for å inkludere en smitteførende giver etter intervju og spørreskjemagjennomgang, eventuell tidligere antibiotikabehandling og bakteriens mulighet for å overleve i tappede blodprodukter inntil transfusjon kunne finne sted. Også muligheten for effektiv helbredende behandling ved eventuell smitte ble vurdert. Et samlet fagmiljø og helsemyndighetene sto bak denne beslutningen (10).
Også i andre land fant tilsvarende diskusjoner sted. I Danmark og på Island har all syfilistesting opphørt. Sverige og Tyskland har samme praksis som Norge, mens man i de øvrige land i Europa fortsatt tester ved hver donasjon. EUs bloddirektiv krever imidlertid ikke syfilistesting (11).

Det ble i midten av 1990-årene fra Folkehelseinstituttet anbefalt å benytte spesifikke tester ved primærtesting og screening med tanke på syfilis. Dette ble gradvis implementert ved laboratoriene, og kort tid etter tusenårsskiftet var endringen gjennomført overalt. I Veileder for transfusjonstjenesten står det at spesifikk syfilistest skal benyttes (12).

\section{Aktuell hendelse}

Den aktuelle blodgiver ble første gang registrert ved blodbank C i 1985 og var da syfilisantistoffnegativ. Vedkommende var donor ved denne blodbanken frem til 1988, hvoretter vedkommende etter et opphold ble registrert som ny giver og igjen testet syfilisantistoffnegativ ved blodbank B i 1993. Ved begge disse testingene ble kardiolipintester benyttet ved screeningen, slik praksis var da. Blod ble gitt ved blodbank B frem til 2007. Giveren byttet da igjen blodbank og ble funnet positiv for syfilisantistoff. Denne gang ble spesifikk treponematest benyttet. Supplerende syfilistester utført ved Folkehelseinstituttet bekreftet disse funnene. Imidlertid var giveren i perioden 1998-2001 også innom et fjerde sted - blodbank D. Ved denne blodbanken ble ikke syfilistesting utført.

Siden 1993 hadde blodgiveren gitt blod ved blodbank $B$ og ved blodbank $D$, hvor fraksjoner ble gitt til $i$ alt 53 pasienter fordelt på sju norske sykehus. 19 av pasientene fikk trombocyttkonsentrat og 34 erytrocyttkonsentrat. I 2007 var 21 (40\%) av disse pasientene i live. Disse ble forsøkt informert og innkalt til testing. $20(95 \%)$ ble bekreftet informert, og 18 (86\%) møtte til testing. Alle var syfilisantistoffnegative (tab 1).

Ved kun ett av de involverte sykehus ble journalene til avdøde blodmottakere gjennomgått. For ingen av de 11 blodmottakerne var det holdepunkter for at det hadde vært påfølgende syfilisinfeksjon.

I alt betyr dette at 29 pasienter $(55 \%)$, hvorav 18 i live og 11 avdøde, er undersøkt eller vurdert med tanke på syfilis, uten at det er funnet tegn til blodoverført syfilissmitte.

I kjølvannet av denne aktuelle hendelsen besluttet man ved blodbank $\mathrm{B}$ å teste alle bloddonasjoner for syfilisantistoff $i$ en periode, for eventuelt å avdekke ytterligere ikke-erkjente serokonvertanter. I en 12-månedersperiode fra oktober 2007 ble over 40000 donasjoner testet - det vil si at nesten hele blodgiverkorpset ved blodbank B ble testet på nytt. Det ble ikke påvist smittsom syfilis.

\section{Diskusjon}

Før man får gi blod først gang og ved hver donasjon senere må blodgiveren svare på 
Tabell 1 Resultater fra oppfølging av 53 blodmottakere som kan ha mottatt syfilissmitteførende blod

\begin{tabular}{|c|c|c|c|}
\hline & \multirow[b]{2}{*}{ Totalt } & \multicolumn{2}{|c|}{ Blodprodukter fra } \\
\hline & & blodbank B & blodbank D \\
\hline Mottakere & 53 & 46 & 7 \\
\hline I live & 21 & 18 & 3 \\
\hline Informert & 20 & 17 & 3 \\
\hline Testet negativ & 18 & 17 & 1 \\
\hline Testet positiv & 0 & 0 & 0 \\
\hline Informert, ikke møtt & 2 & 0 & 2 \\
\hline Usikkert om informert & 1 & 1 & 0 \\
\hline Døde & 32 & 28 & 4 \\
\hline
\end{tabular}

spørsmål om sykdom og smitterisiko. Dette kan danne grunnlag for å nekte blodgivning permanent eller midlertidig og anses som et viktig infeksjonsforebyggende tiltak i transfusjonssammenheng. Likevel kan det glippe ved asymptomatisk sykdom eller ved underkjenning av reell risiko og symptomer, noe som er mulig ved syfilis.

Når det gjelder blodgiveren som ble funnet negativ ved testing i 1993 og positiv i 2007, foreligger det to muligheter: Det har enten vært reell syfilissmitte en gang i det aktuelle tidsrom eller syfilistesten (kardiolipintest) som ble utført i 1993 (og ev. den i 1985) var falskt negativ. Den aktuelle blodgiveren var imidlertid positiv i kardiolipintesten i 2007. Dette gjør det sannsynlig at smitte har funnet sted etter 1993. Spørsmålene blir da når og hvor lenge blodgiveren var smittsom. Nedfryste serumprøver tilbake til januar 2006 var også positive. Vedkommende må derfor ha vært smittet en gang i løpet av de 12 årene før 2006. Blodgiveren har vært smitteførende maksimalt ett år og kan i denne perioden ha blitt tappet for smitteførende blod.

Det er udiskutabelt at syfilis kan smitte via blodtransfusjon, men likevel er ikke syfilissmitte til aktuelle mottakere avdekket. Dette kan skyldes at den eller de aktuelle mottakerne døde av annen årsak og ikke ble vurdert eller at det ble gitt antibiotika under transfusjonen eller i tiden umiddelbart etterpå. Det er imidlertid overveiende sannsynlig at eventuelle levende syfilisbakterier uansett døde under lagring før transfusjonen fant sted. Erytrocyttkonsentrat oppbevares ved $+4{ }^{\circ} \mathrm{C}$ før transfusjon, og syfilisbakteriene dør gradvis ved denne temperaturen i løpet av 48-72 timer, avhengig av den opprinnelige mengden $(13,14)$. Trombocyttkonsentrater oppbevares ved $22{ }^{\circ} \mathrm{C}$, men med en anriket $\mathrm{O}_{2}$-tensjon på ca. $15 \%$. Syfilisbakterien, som er strikt anaerob, dør etter kort tid ved en $\mathrm{O}_{2}$-tensjon på over $1-4 \%$ (4). I Norge er det meget begrenset bruk av nytappet fullblod, kun 50-100 enheter transfunderes per år (15). I tillegg blir trolig under $10 \%$ av blodkomponentene gitt $\mathrm{i}$ løpet av 72 timer etter tapping.

Ferskfryst plasma til transfusjon gjennomgår viderebehandling som dreper alle bakterier. Syfilissmitte fra disse produktene forekommer derfor ikke.

Ekspertgruppen ga på denne bakgrunn følgende anbefalinger:

- Man bør ikke starte generell syfilistesting av alle bloddonasjoner nå

- Nåværende syfilistesting av nye blodgivere opprettholdes som før (primært som surrogatmarkør på tidligere uønsket atferd)

- Spesifikke treponematester skal benyttes klinisk eller serologisk med tanke på syfilis,
Oppgitte interessekonflikter: Ingen

Pasienten har gitt samtykke til at artikkelen blir publisert.

Litteratur

1. Tramont EC. Spirochetes. Treponema pallidum (syphilis). I: Mandell GL, Bennett JE, Dolin R, red. Principles and practice of infectious diseases. 6. utg. Philadelphia, PA: Elsevier/Churchill Livingstone, 2005: 2768-85

2. Larsen S, Steiner B, Rudolph A. Laboratory diagnosis and interpretation of tests for syphilis. Clin Microbiol Rev 1995: 8: 1-21.

3. Egglestone SI, Turner AL. Serological diagnosis of syphilis. PHLS Syphilis Serology Working Group. Commun Dis Public Health 2000; 3: 158-62.

4. Norris SJ, Pope V, Johnson RE et al. Treponema and other human host-associated spirochetes. I: Murray PR, red. Manual of clinical microbiology 8. utg. Washington D.C.: ASM Press, 2003: 955-71.

5. Nilsen $\emptyset$, Blystad H, Aavitsland P. Gonoré og syfilis i Norge 2007. MSIS-rapport 2008; 38: 8.

6. Eberson F. Engman ME. An experimental study of the latent syphilitic as a carrier; preliminary communication. J Am Med Ass 1921; 76: 160-8.

7. Morgan HJ. Factors conditioning the transmission of syphilis by blood transfusion. Am J Med Science 1935; 189: 808-13.

8. Orton SL, Dodd RY, Williams AE et al. Prevalence of circulating Treponema pallidum DNA and RNA in blood donors with confirmed positive tests. Transfusion 2002; 42: 94-9.

9. Orton S. Syphilis and blood donors: what we know what we do not know, and what we need to know. Transfusion Med Rev 2001; 15: 282-91.

10. Ørjasæter H. Røde Kors i blodgiver- og transfusjonstjenesten gjennom 67 år. Norges Røde Kors Blodprogram. Oslo: Røde Kors, 2002: 73

11. Om blodforskriften - med endringer fra 1. januar 2007. Forskrift av 4. februar 2005 nr. 80. Rundskriv 1-1/2007. Oslo: Helse- og omsorgsdepartementet, 2007

12. IS-1414 Veileder for transfusjonstjenesten i Norge. 5. utg. Oslo: Sosial- og helsedirektoratet, 2006: 23.

13. Van der Sluis J, Onvlee P, Kothe F et al. Transfusion syphilis, survival of Treponema pallidum in donor blood. Vox Sang 1984; 47: 197-204.

14. Van der Sluis J, Tate K, Vuzeski V et al. Transfusion syphilis, survival of Treponema pallidum in stored donor blood. Vox Sang 1985: 49: 1390 -9.

15. Flesland $\varnothing$, Bergan TO. Blodtransfusjonstjenesten i Norge. Statistikk for 2006. Oslo: Norsk forening for immunologi og transfusjonsmedisin, 2007: 8.

Manuskriptet ble mottatt 28.8. 2008 og godkjent 28.1. 2010. Medisinsk redaktør Are Brean. 